\title{
Islam, Modernity, and Democracy in Contemporary Turkey: The Case of Recep Tayyip Erdoğan
}

\section{Metin Heper and Şule Toktaş}

Bilkent University

Ankara, Turkey

$\mathrm{F}$ rom Ottoman times to the present, Turkish Islam has come to have an increasingly secular face. The Ottoman Empire ruled a society that evinced, among other things, a mosaic of religions as well as sects.

Consequently, it could not afford to subscribe to a particular version of Islam and thus impose upon its subjects a uniform faith and practice. For the same reason, when in the nineteenth century various religious and/or ethnic groups sought to establish their own independent political entities, the rulers strived to hold the empire together by resorting to the secular concept of Ottomanism. This was perceived at the time as an all-encompassing civic notion of loyalty to the state. Even toward the end of the century, when there were no longer non-Muslim elements, Ottoman rulers sought salvation in pan-Islamism. There was no turn to Islam-as-theocracy; Islam was expected to engender loyalty to the Ottoman sultan.

Following the establishment of the republic in 1923, the founders of the new state attempted to further secularize the polity and society. They attributed the fall of the Ottoman Empire to the opposition of the remaining vestiges of 'retrogressive' Islam and Westernizing reforms. Taking their cues from the teachings of the Enlightenment, they wanted the new Turk to be someone who would think logically. Consequently, not only did they pronounce the new republic secular, but they also took extensive measures to transform the cognitive make-up of the people from 'dogmatic' to 'rational' thinkers. For many Turks, what has been called "Muslim secularism," that is, a formal 
recognition of the Muslim character of society, for example, has not been acceptable. Most Arab governments, including that of Egypt, opted for this less extreme form of secularism. ${ }^{1}$

On the whole, the Turkish version of secularism has been a successful project. In time it led to a large number of people taking religion as a system of belief and morality rather than a prescriptive set of political rules. Most began to show strong signs of being 'sincere Muslims' who regularly practiced their religion in their personal and communal lives and acted according to the moral principles of Islam, but otherwise had a secular discourse and praxis. ${ }^{2}$ Consequently, from the mid-1940s onward, Turkey became the sole Muslim country where greater numbers of people perceived democracy as "the only game in town." ${ }^{3}$ More recently, in the wake of September 11, 2001, Turkey turned out to be the only Muslim country that gave its support to the United States-led "War against Terror."

It is not unusual that Islam has become hostile to secularization and modernity in general in those Muslim countries that had in the past been colonies of the West. In such settings, colonial countries were considered to be carriers and defenders of a mixture of aggressive Christian proselytism and the new secularization. ${ }^{4}$ Turkey has never been a colony, which, along with its heritage, provides another example of "Turkish exceptionality."

It was in such a context that from 1969 to the present, religiously oriented political parties became part and parcel of Turkish political life. The initiative for the founding of the first of these political parties (National Order Party Milli Nizam Partisi-MNP) came from the Nakshibandi religious order. Its then leader, Shaykh Esat Zahit Kotku, took moral development as a prerequisite for both material development and political stability. Moral development was to come about by internalizing virtues derived from Islam. However, the Shaykh's ultimate goal was this-worldly; in his project of revitalizing Turkey, Islam was encouraged to promote something similar to the Protestant Ethic. In the final analysis, what Shaykh Kotku was trying to do was resurrect "the moral community" of Ottoman times when common folk lived by the principles of Sharī'ah. ${ }^{5}$

It is true that both the MNP and its successor political parties (National Salvation Party [Milli Selamet Partisi-MSP]; Welfare Party [Refah Partisi-RP]; and Virtue Party [Fazilet Partisi-FP]) drifted from the premise that informed Shaykh Kotku's project. All of those parties were engaged in a discourse and sometimes praxis that had at least some elements of political Islam. For instance, Necmettin Erbakan, who was chairman of the MNP, MSP, and RP, once said, "We will definitely come to power; however, whether it will be through the shedding of blood or not is an open question." Similarly, at a public meeting of the MSP held in the mid-Anatolian conservative city of 
Konya, supporters of the MSP did not stand while the national anthem was played. The MNP, RP, and FP were closed by the Constitutional Court. The MSP was banned following the September 12, 1980, military intervention, along with all other political parties.

At the same time, from 1969 to the present, religiously oriented political cadres in Turkey have increasingly adapted themselves to the secular and democratic system. However, during the MNP rule (1969-70), religion was not seen as compatible with secularism. Before the closure of the FP in June 2001, some leading members of the party thought that state and religion should not tread into each other's domains. In the earlier period, even women who covered their hair were not allowed to take part in party activities; in the latter period, women who not only did not cover their hair but also publicly consumed alcoholic drinks were elected to Parliament from these parties.

Orthodox factions within these parties have not looked with sympathy on these developments. Erbakan backed these factions. Following the banning of the RP in January, 1998, the conflict in question led to an outright split among the cadres of the successor FP. The so-called Innovators (Yenilikçiler) challenged the so-called Conservatives (Gelenekçiler). Recep Tayyip Erdoğan was an important figure among the Innovators. Initially, Conservatives had the upper hand. Although banned from active politics following the closure of the RP, Erbakan continued to exercise influence in the party by helping Conservatives to dominate. When the FP was closed, the Innovators left the party. The Erbakan faction formed its own party - the Felicity Party (Saadet Partisi-SP). The Innovators founded the Justice and Development Party (Adalet ve Kalkinma Partisi-AKP). Erdoğan became the leader of the AKP.

Erdoğan has been very popular since he was a candidate for mayor in 1994. In those local elections, while the nationwide RP vote was 19 percent, the $\mathrm{RP}$ received 25 percent of the vote in Istanbul. In a poll taken in the province of Istanbul in July 1998, 15.2 percent of respondents thought of Erdoğan as Turkey's best politician. Support for Bülent Ecevit (former prime minister) was 7.6 percent, for Süleyman Demirel (former prime minister and president) it was 7.4 percent, for Erbakan (former prime minister) 6.8 percent, for Mesut Yllmaz (former prime minister) 4.6 percent, and for Tansu Çiller (former prime minister) 2.8 percent. ${ }^{6}$ A nationwide survey in June, 2001, showed that 65.7 percent of those who had voted for the FP at the April, 1999, national elections thought that a new political party led by Erdoğan would be successful. Those supporting a new party under Erbakan were only 4.6 percent. ${ }^{7}$ A July, 2001, survey corroborated the June, 2001, survey results. ${ }^{8}$ In summer, 2002, several polls indicated the AKP had the support of the plurality of the voters. 
As stated, Erdoğan is a popular leader. However, many secular Turks find him problematic. In their view, Erdoğan had and continues to have radical Islamist tendencies, and is inclined toward political Islam (Islam shaping public law and public policy). They summarily reject the proposition that he may have changed over time. To them, Erdoğan has been engaged in the wellknown Islamic practice of dissimulation (takiyye) all along, that is, hiding one's true intentions until the time is appropriate for them to be disclosed. Only a few among them are willing to give Erdoğan the benefit of the doubt.

This article addresses the following crucial questions: Has Erdoğan been a radical Islamist who sympathizes with political Islam? Has he changed over the years? If he has changed, has that change been such that he would not find it difficult to function within a liberal-democratic political regime? These, we think, are crucial questions with respect to the issue of the consolidation of democracy in Turkey. In Turkey, the military accepts the fact that final authority constitutionally belongs to the civilian government, but, on the other hand, it intervenes in politics if in its opinion the country faces the threat of political Islam (as well as separatist nationalism). We think the Erdoğan case may show whether or not Turkey is on the way to adapting its Islam to the requirements of a liberal democracy, which it is also trying to institutionalize.

\section{Background, Education, and Personality}

Recep Tayyip Erdoğan belongs to Turkey's cultural periphery. He was born in Kasımpaşa (1954), a lower middle-class district in Istanbul. His father was a captain in the state Maritime Agency and his mother a housewife. In order to contribute to the family income, Erdoğan sold lemon, spices, breadcake, and drinking water on the streets. Consequently, he has grown up aware of the values and aspirations of the common folk. This may have had an impact on his emphasis on authenticity, to which we turn below.

Erdoğan is married. He has four children; all but one attends school abroad. ${ }^{9}$ From this we can only conclude that Erdoğan has an open mind toward non-Muslim countries.

Erdoğan had a modernist education and career before entering politics. After graduating from an Imam Hatip School, he obtained a B.A. degree from the department of economics and trade of Marmara University in Istanbul (1980). Erdoğan knows Arabic and some English. He has worked as an executive manager in various private corporations in the wholesale food sector.

Erdoğan has been actively involved in politics since 1969. He started his political career in the National View Association (Milli Görüş Teşkilatı), which was a think-tank of both the National Order Party and the National Salvation Party (MSP). He then led the youth division of the MSP's Beyoğlu District in Istanbul. In 1984, he became the head of the Welfare Party's (RP) Beyoğlu 
District Branch. The next year, he was entrusted with the administration of the RP's Provincial Party Organization in Istanbul. In 1986, Erdoğan was elected to the central executive committee of the RP. In the 1989 local elections, Erdoğan was the RP's candidate for the Beyoğlu mayoralty. Although he lost, he tripled RP votes in Beyoğlu compared to previous elections. In the 1994 local elections, the RP nominated him as their candidate for Istanbul metropolitan mayor. Although he competed against several nationally prominent candidates from other parties, he nevertheless won the mayoralty. He served in this last post until 1998. That year, he received a prison sentence of four and a half months and was banned from active politics. ${ }^{10}$ As noted, he played an important role following his release in the Innovators movement in the Virtue Party and, upon the closing of that party, formed his Justice and Development Party.

What was Erdoğan's approach to education? Erdoğan once said, "There are two persons whose hands should be kissed [read, two persons who should be accorded respect]. First is the teacher who conveys knowledge to others. The second is one's father. The hands of babies too may be kissed because they are a symbol of hope." ${ }^{11}$ One sees in this statement not only his esteem for learning, but also his conception that the cosmos may change for the better. Indeed, when he was a candidate for mayor, Erdoğan took private lessons on municipal problems from staff members of Istanbul University and Istanbul Technical University. As he was starting to serve his prison sentence, Erdoğan said that he was going to take the opportunity to study economics and politics, as well as improve his English. ${ }^{12}$ While he was Istanbul metropolitan mayor, Erdoğan saw to it that workers at both the metropolitan and district municipalities attended such courses as comparative history of municipal administration, aesthetics, history of art, urban affairs, planning and zoning, protection of the environment, infrastructure engineering, construction techniques as well as morals and ethics.

Erdoğan learned from experience. He was ready to admit that he had made mistakes in the past. For instance, he pointed out that while he was mayor, his municipality could not build an adequate number of multiple-story parking places. For this, he did not blame others. ${ }^{13}$

What can be said about Erdoğan's personality? There were four major influences on his life: (1) his father, (2) Kasımpaşa - the neighborhood in Istanbul where he was raised, (3) his teacher at the primary school he attended, and (4) Sufism. His father was an authoritarian personality. ${ }^{14}$ Erdoğan also has strict principles, which may be attributed to his father's influence. Erdoğan was the head of the Welfare Party's youth organization in Istanbul when he played football in his youth. Yet, in his football club, he abstained from espousing party propaganda. Erdoğan respects rules. Although he has 
intense religious feelings, for a long time he wore shorts while playing football, despite the fact that Islam forbids men to display the parts of the body between belly and knees. Also, during the sixteen years he played football, Erdoğan was only once sent off. Erdoğan respects authority figures. When he was young, Erbakan was his idol. ${ }^{15}$ He even named one of his sons after Erbakan.

Erdoğan is not an easygoing man, which seems to be related to the fact that he was brought up in Kasımpaşa. In Erdoğan's own words, in that neighborhood "there were very close relations between families. There existed a shared conscience of the neighborhood. The people who lived there acted like the members of the same family." ${ }^{16}$ Kasımpaşa is well known for its bravado culture. Erdoğan has pointed out its impact on him as follows, "My manliness, bluntness, and principled conduct derive from my roots [in Kasımpaşa]." ${ }^{17}$ One does observe defiance in Erdoğan. For example, some in the party had objected to Erdoğan's playing football. He continued to play nonetheless. At times, Erdoğan has been too outspoken for someone living in Turkey. Once, when an officer had criticized the RP's stand against secularism, Erdoğan snapped back: "That officer should take off his uniform before making such statements." ${ }^{18}$ When in April, 1997, the military, through the National Security Council, forced the RP-True Path Party coalition to adopt extensive measures against the danger of "political Islam," Erdoğan urged RP leaders to stand firm. ${ }^{19}$ On still another occasion, he scolded a judge because the judge had not acted in a decisive manner concerning the allegations of improper behavior at a polling booth. ${ }^{20}$ It has also been suggested that Erdoğan sometimes voiced opinions or proposals incongruous with orthodox wisdom not only because he was from Kasımpaşa, but also to draw attention to himself when he was not yet a well-known public figure. It was during this early period in his political career that he suggested that "Ayasofya should be opened to Muslim prayers" [Ayasofya was the St. Sophia Church during the Byzantine period. It was converted to a mosque following the conquest of Istanbul by the Ottomans (1453), and was made into a museum during the republican period]. On another occasion, he said, "If I am elected [mayor] I shall ask Pierre Cardin to stage a fashion show of dresses with veils." 21

It is true that Erdoğan is a university graduate, which in Turkey means one belongs to the elite. Yet, being from Kasımpaşa and having had close relations with the people there for a long time has given Erdoğan the feeling of belonging to the Turkish cultural periphery. He once observed, "In this country, there is a segregation of Black Turks and White Turks. Your brother Tayyip belongs to Black Turks." ${ }^{22}$ Also, unlike most members of the elite in Turkey, Erdoğan went to the same barbershop his whole life and, from time to time, did his own shopping. The feeling of belonging to the periphery and acting the part of the man on the street may have led him to challenge the 
officer who had criticized the RP. For him, the officer represented the cultural as well as undemocratic center.

We focus on the above idea because, as noted, Erdoğan values authenticity. For example, while Erbakan preferred elaborate dress and Versace ties, Erdoğan stayed away from such eye-catching clothes. Erdoğan is proud to represent indigenous values and attitudes. Although not against Turkey's joining the European Union (EU), he thinks that in doing so, Turkey should be careful not to shed its own cultural heritage. He wants to see Turkey make "a meaningful contribution to the mosaic of cultures that one observes in Europe." ${ }^{23}$ His motto is "a local-oriented stance in a globalizing world." ${ }^{24}$ Following the February, 2001, economic crisis, the government had recruited World Bank economist Kemal Derviş to rescue its economy. Erdoğan had the following to say about Derviş: "I myself do not have an American passport. My mother is not a German. I am a one hundred percent citizen of this country. I am not an import commodity!" ${ }^{25}$ Erdoğan was lamenting the fact that a Turk who had spent most of his/her adult years in Turkey was not given a chance to save the country from its financial conundrum.

His primary school teacher in Kasımpaşa encouraged Erdoğan to attend the Imam Hatip School situated at the opposite side of the Golden Horn from Kasımpaşa. Even before his years at that school, Erdoğan had become a practicing Muslim, doing his prayers on a regular basis. One day at the Imam Hatip School, the teacher asked his pupils whether anyone knew how to conduct Islamic prayers. Erdoğan indicated that he did. Thereupon the teacher laid a newspaper on the floor and asked Erdoğan to pray. Erdoğan refused, arguing that it was not proper to pray on a newspaper because there were pictures on it. ${ }^{26}$

Others too at the Imam Hatip School left a strong impression on Erdoğan. He once observed: "I owe everything to the Imam Hatip School I attended. My life was predestined in that school. I have learned there patriotism, love for fellow human beings, service for the country, worship of God, environmental sciences, spirit of solidarity, and wishing for others what I want for me." 27 Erdoğan was a devout Muslim from a very early age. He always prayed before playing football. When later he had to make a choice between playing football and shaving off his beard, he gave up the football.

In his adult life, Erdoğan attended the İskenderpaşa Seminary (dergah) of the Nakshibandi Shaykh Mehmet Zahit Kotku. Historically, the Nakshibandis aimed at establishing the reign of Sunni morality in this world. In the Ottoman Empire, they strove to achieve strength through unity in belief. The Nakshibandis did not question the legitimacy of the Ottoman government. Shaykh Kotku, who died in 1980, had an extraordinary sensitivity to modernity. ${ }^{28}$ Among other things, his seminary did not force its attendants to 
wear traditional Islamic dress, as was the case in the İsmail Ağa Seminary another Nakshibandi seminary in Istanbul. ${ }^{29}$

İskenderpaşa Seminary must have had a great influence on Erdoğan. He himself pointed out that Sufism had an impact on him. ${ }^{30}$ Sufism is both a high and low culture; the former dimension of Sufism is characterized, among other things, by fine poetry. ${ }^{31}$ Young Erdoğan was fond of participating in debates at school. In 1973, he won a poem-reciting competition that the Istanbul daily Tercüman held among students. ${ }^{32}$ During those years, Erdoğan often resorted to reciting a poem in order to more effectively as well as eloquently express himself. This he continued to do later in his life too. In fact, one of the reasons he was convicted in 1998 was a poem with which he had started a public speech in the city of Siirt in southeastern Turkey. ${ }^{33}$ Not unexpectedly, Erdoğan is also a sentimental person. When he was going to serve his prison sentence, he bade farewell to his supporters by saying, "I wanted to carry to the public space your wishes and aspirations. Those wishes and aspirations are locked up in the secluded rooms of your modest homes. They are conveyed to others only by the hopeless expressions on the faces of your children who have no jobs, and are silently kept in the wounded hearts of your mothers and fathers. I love your voices, because I am one of you. I do not regret what I have done, because we together have done it." ${ }^{34}$ Nuran Yildiz of Ankara University has portrayed Erdoğan as someone who "is friends with heavens, lives by his heart, has a heart that is filled with poetry, and has a symbolic discourse." 35

Erdoğan often resorted to a terminology informed by Islamic themes, if not by Islamic substance. He has referred to his father's moving from his home town in the Black Sea region in northwestern Turkey to Istanbul as the Hegira (Hicret), the emigration of the Prophet from Mecca to Medina in A.D. 622 to escape from his enemies. ${ }^{36}$ When he became the mayor of Istanbul, he pronounced himself the imām of that city. When he was criticized for what he had said (for imām in everyday Turkish means prayer leader), Erdoğan retorted by saying, "When you hear the word imām, you only think of the person who leads the prayers in a mosque. In Islam, imām refers to the person who has the authority to rule." ${ }^{37}$ Erdoğan opened the very first session of the administrative council of his municipality in Istanbul with the chanting of Fätihah. He was again under fire, because in everyday Turkish, Fätị̆ah refers to a particular verse in the Qur'ān, which is repeated for the dead. Erdoğan reminded all that Fätihab is the opening chapter of the Qur'ān. ${ }^{38}$

Erdoğan has often been misunderstood. He once said, "You never believe me. You always read something else into what I am trying to say because you load different meanings to the terms I use. ${ }^{\prime 39}$ In the interview one of the present authors had with him, he frankly pointed out that sometimes he cried when the media criticized him "without some mercy." Lately, his response 
to questions has been "would you believe me if I tell you what I think or do?"

\section{Islam and Democracy}

As noted, Erdoğan has a Sufi take on Islam. An hadith often mentioned by Sufis, points to two types of jibād, or holy war — the lesser jiba $\bar{a}$, which is against the enemies of Islam on the battlefield and the greater jibād against the nafs, the lower instincts in man. Shaykh Kotku who, as noted, had played a critical role in the emergence of religiously oriented political parties in Turkey, seemed to have the greater $j i b \bar{a} d$ in mind when he talked of the need for "moral development." Erdoğan reads jihād along the same lines: "Religions are a means for the happiness of human beings. God says Islam aims at improving the welfare of the people." 40 Sunni Islam, of which Erdoğan is a devotee, also attributes importance to the perfection of conscience because, according to Sunni Islam, one cannot create an orderly and tranquil life by legal restrictions alone.

In Sufism, an effort is made to subdue lower instincts and open a space in one's heart for God. Erdoğan thinks that God created man with a potential for attaining a higher level of being. In his opinion, man climbs the steps to that higher level to the extent to which he internalizes the goodness God radiates. ${ }^{41}$ Erdoğan once remarked: "The value of a thing is measured by the worth of its creator. When we look at the Selimiye [mosque in the city of Edirne in northwestern Turkey), is it possible not to remember [its architect] Sinan? .. . [Similarly] . . . it is inconceivable not to think of God when one looks at man? If an eye looks at man and does not see God, it is not a good eye." ${ }^{42}$ In Erdoğan's submission, man is obliged to contribute to the welfare of his fellow man; it is therefore incumbent upon man "to act in ways for which God grants His acquiescence [rrza]." ${ }^{` 3}$ As noted, Erdoğan took Islam as his basic reference, and derived from it a set of moral principles for personal and communal life. For instance, he did not approve of some of the TV programs broadcasted on New Year's day because he did not find them sober enough. ${ }^{44}$ Similarly, he does not sit cross-legged, for this shows disrespect for others. ${ }^{45}$

According to Erdoğan, one can serve fellow human beings not only through efforts to morally improve oneself but also through helping others in their endeavor to improve themselves. Consequently, he considered being an Imām as serving as a guide (rebber) for his fellow human beings. In his own words, "A guide should only show the way to goodness and not to badness. If he has the means at his disposal of discouraging people to be engaged in bad behaviour he should not refrain from using them." ${ }^{46}$ With this reasoning, 
he did not as mayor allow the serving of alcohol in restaurants run by his municipality. However, he did not restrict other restaurants from so doing, including those operating in places let to them by the municipality. As a devout Muslim, he must have known that Islam does not allow the forceful imposition of religious beliefs and tenets on others. Still, Erdoğan was criticized for this policy. According to Islam, God left it to its believers to differentiate between the pious act (sevap) and sinful behavior (günah). Erdoğan responded to that criticism by arguing, "We do not try to substitute our own judgement for the judgement of our fellow believers. Yet, we think God expects from us to create conditions favourable for good acts. Would you give a weapon to someone who is determined to kill himself? Would you willingly facilitate such a bad act?" ${ }^{47}$ In William E. Shepard's terminology, Erdoğan can be seen as a moderate secularist. Shepard argues that moderate secularists "follow an Islamic of code of ethics in their personal lives. They may be actively concerned with dacwa . . in the sense of calling Muslims to more ... ethical practice." ${ }^{48}$

Erdoğan has never distinguished between Muslims who seek the acquiescence of God and those who do not because he believes all were created by God and therefore are equal. In any case, he has stated that "... in this country we live together; if the country goes under we will all perish." ${ }^{\not 9}$ In fact, during Erdoğan's bid for mayoralty in 1994, RP members in Istanbul took their campaign to bars and brothels, among other places. It was reported that in providing fellowships to poor students, Erdoğan's municipality did not favor Sunnis at the expense of the Alevis. ${ }^{50}$ Erdoğan was against discriminatory behavior towards non-Muslims, too. His municipality helped renovate not only mosques, but also churches and synagogues. Erdoğan once said, "I do not think a person who is a genuine believer would wish to harm the community, no matter what his religion is. . . In all believers, one comes across tolerance, love, and an instinct for helping fellow man. ${ }^{51}$ Let us note in passing that Erdoğan does not look upon women as second class citizens. His wife is covered not because Erdoğan had asked her to cover, but because they "sat down, found out that their worldviews overlapped, and then got married." 52

Sufis consider all people, whatever their beliefs and merits, as guests of the Sufi saint. Similarly, Erdoğan thought his administration should embrace all Istanbulites. While running for mayor, he warned those around him, as follows: "Do not forget, we are not a communal group; we are a political party. We are the party of Turkey; we should open our arms to everybody." ${ }^{53}$ In everyday life, too, Erdoğan has not been an incurable partisan; although he is a fan of Fenerbahçe football club, he attended Galatasaray football club's European cup games with a yellow and red scarf, the colors of Galatasaray. 
Erdoğan carried this particular philosophy to the public space. He is of the opinion that a politician should benefit from the "pluses of the politicians who preceded him/her and arrive at a new sythesis." ${ }^{4}$

On the other hand, being a devout Muslim, Erdoğan always tried to keep religious fervor high in the community. His opening of the HABITAT-II in Istanbul in 1997 by a performance of the Ottoman-style military band, his intention to build a grand mosque near the Taksim Square in Istanbul where national days are commemorated, and even his encouraging people to play the role of rain-makers ${ }^{55}$ is evidence of this. However, it is also significant that when attacked by the secular intelligentsia for each of these projects, he did not insist upon them.

Erdoğan has respect for democracy. When convicted in 1998, he criticized the court ruling but not the political regime itself: ${ }^{56}$ "In principle, we have respect for judicial rulings. This does not mean that we accept wholeheartedly unjust court decisions.... [On the other hand], we will exercise all our rights within a democratic framework." ${ }^{57}$ In the same speech, he urged his followers "to try to remove governments from power only via the ballot box." 58

Historically, Muslims attributed legitimacy to different types of political regimes. For them, the end was far more important than the means. For Erdoğan, too, democracy like Islam was a means to a higher end - that of "saving of lives." Erdoğan said, "It would be wrong to take democracy as an indispensable prescription for survival [under all circumstances]. Each system is good or bad according to the people in the positions of power. For instance, in some kingdoms there had been widespread poverty, in other cases realms were ruled in a competent manner." ${ }^{60}$

Erdoğan's conception of a properly functioning democracy is informed by the Islamic institution of shürah, or consultation. He defined democracy as an exchange of ideas. He once observed: "I define myself as a democrat. I think my beliefs and thoughts are in line with democracy for, in my opinion, democracy is consultation to the widest extent possible." mayor, members of the Welfare Party and the Independents together were in the majority in the administrative council of the municipality. Yet, Erdoğan asked members from the two secularly oriented political parties - the Motherland Party and the Republican People's Party — to also take part in the standing committees. He pointed out that democracy was not "just elections, but also that of authorizing one's representatives to monitor and supervise those in power." ${ }^{62}$

Since Erdoğan wished to see consultation among a large number of people, he opposed election barriers. He urged politicians to get used to coalition governments. On the other hand, as would be expected, he believed the goal of democracy was not just the aggregation of interests with perhaps 
some regard to long-term interests of the country, but finding out God's consent ( $r z a)$ regarding what is 'just' and 'unjust.' Here, 'just' refers to the primordial underpinning of moral community, which is derived from Islamic tenets. The latter provide criteria for good behavior, for which one has God's consent. ${ }^{63}$ Once the following exchange took place between Erdoğan and an interviewer:

- Erdoğan: 'Other political parties expect to quickly reap the benefits of what they have achieved. In contrast, the members of our party expect to be rewarded for their deeds in the other world. This is very important.'

- Interviewer: 'What is that reward? Is it the Paradise or God's consent?

- Erdoğan: 'God's consent. ${ }^{64}$

For the sake of improving the moral integrity of community, Erdoğan has sometimes shown that he is not a genuine democrat. What role has Erdoğan really attributed to the people in his democracy? Here, the record is mixed. The present authors have come across four different types of responses to Erdoğan's question: (1) "Our real goal is God's consent. People's approval is of secondary importance"; 65 (2) "God's consent is important. We would have people's approval if our deeds conform to what God has consented to"; 66 (3) "One should pursue policies that would overlap with people's wishes"; ${ }^{77}$ (4) "A movement that does not have people's support behind it cannot be successful. ${ }^{68}$ People with their vast experience, foresight, and sagacity make sense of everything better than all of us can do. What we should do is not to tell people what to do, but to pay attention to what people are telling us." ${ }^{69}$

What can one make of this seemingly mixed set of statements? We surmise the following: for Erdoğan, God's consent is of utmost importance, for God is the primary source of all good deeds. Erdoğan wants to underline this point (first statement). He has in mind practicing Muslims who have for a long time opened a space in their hearts for God; thus, they have to a great extent internalized what has been revealed to them by God; consequently, they would be expected to wholeheartedly welcome what God has already consented to (second statement). Erdoğan wishes to reconcile his subscription to what God has consented to with the wishes of the people, because he wants his party to turn into a "party of Turkey" (third statement); Y1lmaz is no longer an Islamic democrat, but has become a democratic Muslim (fourth statement). We return to the crucial last point below.

Erdoğan is for intra-party democracy. In Islam, those who do not rule in accordance with God's consent are tyrannical persons, and no one is allowed to resort to personal rule. The First Caliph Abū Bakir had observed "As long as I act along the lines God and His Prophet set for us, you should obey me. If I rebel against my God, there is no need for you to obey me any longer." In 
the interview mentioned above, Erdoğan was asked, "You said you are not the follower of a person but the system; would you say that out loud if you see Erbakan not on the right track?" Erdoğan responded to this question in the affirmative: "For us the most important thing is not to be a slave to man, but to the Right [God]. Even the Prophets said, 'Do not obey us if we leave the right path. ',70

All in all, Erdoğan believes people should love each other, because only then will they have God's acquiescence. The goal in politics too should be that of saving people from their plight. According to Erdoğan, governments in Turkey should have strengthened the republic, while striking a balance between republican principles and the values shared globally. In Erdoğan's view, Turkey first needs a strong economy in order to build a robust republic and safeguard democracy. A viable economy depends upon the adoption of a new governmental philosophy based upon morality. ${ }^{71}$ Erdoğan believes in a secular republic, a democracy based on rule of law, and in people-oriented politics, where the highest value is personal integrity. ${ }^{72} \mathrm{He}$ attributes to democracy the same significance as he does to morality, modernity, and humanity. Erdoğan considers himself a democrat. Yet his ultimate reference is a normative value system derived from mystic Islam.

\section{Political Islam? Erdoğan's Conviction and Beyond}

It is plausible to argue that for Erdoğan, being a Muslim does not necessarily mean he advocates political Islam. For him, Islam is a means of moral self-improvement, which he considers crucial. Yet on April 12, 1998, the State Security Court of the city of Diyarbakir in southeastern Turkey found him guilty of inciting people to hatred on the basis of religion and trying to set up an Islamic state. As noted, his conviction came in the wake of a political speech he had made on December 6, 1997, in the city of Siirt. The High Court of Appeals ratified the decision of the lower court.

What can one make of this conviction? Should one take it as clear-cut evidence of Erdoğan's inclination toward political Islam, negating all he has done? When the courts came up with the prison sentence in question, a pitched controversy arose in Turkey. During the trial, some students of criminal law in Turkey, led by their doyenne, Professor Sulhi Dönmezer, who is a self-proclaimed secularist and Atatürkist, were of the opinion that the speech did not constitute a crime. Furthermore, the public prosecutor of the lower court had asked for Erdoğan's acquittal; one of the three judges of the same court had cast dissenting votes; neither was the decision of the Appeals Court unanimous. ${ }^{73}$ However, a legal analysis of the court decisions in question are beyond the scope of this paper. ${ }^{74}$ On the other hand, a social science perspective of the accusations directed at Erdoğan and in Erdoğan's 
defense would shed further light on the question of whether Erdoğan has basically been interested in his own moral development and that of others or been primarily inclined towards political Islam. In other words, in this part of our article, we are not interested in the validity of Erdoğan's conviction, but rather in what Erdoğan really stands for.

Erdoğan started his speech in Siirt by reciting the following quatrain: ${ }^{75}$

Minarets are bayonets

Domes are helmets

Mosques are barracks

Believers are soldiers

In his speech, among other things, he indicated that his reference was Islam. He pointed out that nobody would be able to stop the calls to prayer in Turkey. If some tried, Erdoğan and others of like mind would become a volcano, a lightning, and explode against them. In other words, they would not become subject to man; they would only bow to what is 'right.'

These statements and poems were interpreted as evidence of Erdoğan's desire to implement the Shari ${ }^{-c} a h$, trying to divide the people of Turkey into 'believers' (dindar) and 'non-believers' (dindar olmayanlar), and inciting 'believers' against 'non-believers.' Erdoğan's depiction of democracy as 'a means' was also taken as 'evidence' that Erdoğan was a subscriber of the non-democratic strategy of "one man, one vote, only once."

Erdoğan defended himself by arguing that he was just a pious person who practiced his religion, and who viewed Islam as the sole source of personal morality and a guideline for day-to-day behavior. "When I say, "My reference is Islam,'" he said, "I mean the same thing as any ordinary Muslim has in mind when he says, 'Thank God! I am a Muslim." "76 He argued that his reference to Shari' 'ah has had the same connotation: "When I say 'I am for Shari' $a b$,' I have the same thing in mind when I say 'I am a Muslim' ... There is no country in the world without a Shari ${ }^{-} a h$. Neither Muslim, Christian, nor Jew would refuse to acknowledge God's rules. People everywhere pay attention to their Sharī $a h .{ }^{\prime \prime}{ }^{77}$ For this reason, Erdoğan thought, a political party's reference too could not be Islam. According to him, the RP was not a religiously oriented party. ${ }^{78}$ Later, he further clarified what he meant when he said his reference was Islam: "My reference is to Islam at personal level. Politically speaking, my reference is the constitution and democratic principles." ${ }^{79}$ Erdoğan argued that "ninety-nine per cent of the people in Turkey adopted Islam as a way of life." He seems to have subscribed to the well-known argument that according to Islam, there cannot be a religiously oriented state, and that the verses in the Qur'ān and the Prophet's hadìths are not about the state but about how rulers should act. 
As noted above, Erdoğan often resorted to symbolic discourse and loaded rather specific meanings to such religious terms as imām and Fätihah. Thus, in all probability, Erdoğan had one thing in mind when he said his reference was Islam while those who accused him of trying to set up a state based on Islam had other things in mind. In his legal opinion about the accusations directed toward Erdoğan, Professor Dönmezer seems to have arrived at the same conclusion. Dönmezer wrote: "Unless one falls into the dilemma of subscribing to radical secularism as a reaction to Islamic fundamentalism, ... [Erdoğan's speech] cannot be construed as a retrogressive discourse. ${ }^{11}$ The public prosecutor of the Diyarbakir State Security Court also argued that in his Siirt speech, Erdoğan took Islam as a source of personal morality: "Islam recommends to its adherents righteousness, honesty, social justice, good character, hard work, and other such moral qualities. Islam asks them to refrain from acts that would harm others. In their personal lives and in their relations with others, everybody in general but Muslims in particular should always keep in mind their moral obligations. Only then many of the problems in society will disappear by their own accord, a consensus will emerge, and a mutual feeling of love will make people respect each other's rights, interests, and freedoms. When the accused [Erdoğan] has stated that his reference was Islam, he only made it known that he longed for such a society to flourish." 82

Concerning the claim that he perceives democracy as a means for setting up a state based on Islam, Erdoğan said, "By that statement, I have wished to make the following point: In every act or activity, one should provide for people's happiness, welfare, and security. A system that is instrumental concerning this particular goal is a means to the end in question." 83 Earlier, Erdoğan had used the same notion of 'a means' ('araç') not only in reference to democracy but also to Islam itself: "It would be inaproppriate to use religion as a means to success in politics. We believe religions are a means to achieve the happiness of the people.... [Similarly], politics is an art of making it possible for people to express their thoughts and beliefs. ... However, I am against the politicization of religion even for this purpose. ${ }^{\prime 44}$ In his opinion, "in order to achieve a certain end making resort to a means that is expected to serve another end is immoral." ${ }^{85}$

If Erdoğan did not have in mind a state based on Islam and, therefore, did not perceive democracy as a means to that end, why did he start his speech in Siirt with the quatrain that seemed to his accusers to incite people to resort to force to accomplish an end, that is, as a lower jihād? First, as we have pointed out above, Erdoğan often expresses himself by reciting emotional poems. Therefore, one should not jump to the conclusion that by starting his speech in Siirt by reading a poem, Erdoğan had the ulterior motive of inciting 
believers to brute action against non-believers. ${ }^{86}$ In his legal opinion, Professor Turhan Tufan Yüce arrived at the same conclusion. He wrote, "The habit of the accused to arouse his listeners sentiment is a tactic often used by the speaker and it is not illegal." ${ }^{\prime 87}$ Erdoğan once noted that a poem is a means of expressing "intense longing (sevda), love (assk), and enthusiasm (beyecan)." ${ }^{88}$ Secondly, it is difficult to argue that with that poem, Erdoğan tried to incite 'believers' against 'non-believers.' He later said, 'As always, I started my speech [in Siirt] by reciting a poem. ... The quatrain I used belongs to Ziya Gökalp who, as an intellectual, rendered invaluable services to the Republic in its early years." ${ }^{\circ 9}$ In fact, the poem with the quatrain in question is in a book recommended to secondary schools by the Ministry of Education. ${ }^{90}$ The quatrain in question was a response to Roman Diogen's quatrine of

I should have the Qur'ān burned

I should have the Kaaba destroyed

[so that] Those who come to the East

Could no longer see domes with minarets

Gökalp, through Sultan Alparslan, who by defeating a Byzantine army in eastern Anatolia in the eleventh century opened the road to Anatolia for Turks, was symbolically answering Diogen with the quatrain that years later Erdoğan read in Siirt. Gökalp thought that what held people together both in the Ottoman Empire and Turkey was their culture, which was primarily a product of Islam. In his defense, Erdoğan similarly argued that in his speech, he had wanted to underline the significance of unity of belief for social unity and the territorial integrity of the country. Indeed, in his speech in Siirt, Erdoğan had said the following: "From Malazgirt [where Sultan Alparslan had defeated the Byzantines] to Canakkale [where in the First World War the Turks had successfully stopped a large Allied fleet], what enabled our ancestors to have one victory after another was . . the unity of belief. ${ }^{91}$ My Brothers, we in this country love everybody without discriminating against any one and we will continue to do so in the future too. We all share the same values. We are all citizens of the Turkish Republic.... For us, there is only one fatherland." $" 2$

Erdoğan had completed his speech in Siirt with another quatrain in order to both pyschologically influence his listeners and to once more underline what helped people to join forces and succeed in their joint endeavors - a morality derived from Islam:

Comes from the altar the Holy Word

Comes to the earth greetings from the infinite heavens

Neither wealth, nor office, nor status

Stand clear: comes to the hearts the Just Order. ${ }^{93}$ 
Professor Doğan Soyarslan, the judges of the lower court and the Court of Appeals in their dissenting votes argued that Erdoğan had appealed in his speech to people's religious sentiments for bringing about social unity. ${ }^{94}$

Since Erdoğan has been interested in moral development rather than a state based on Islam, he has had no problems with either Atatürkism or the secular Turkish state, provided, of course, that the state in question did not discriminate against believers. When he was mayor in Istanbul, Erbakan kept away from Republic Day ceremonies in Ankara, the capital city, but regularly attended them in Istanbul. ${ }^{95}$ When attending those ceremonies, he even carried an Atatürk pin on his lapel. ${ }^{96}$ Erdoğan has pointed out that he was against an "ideological state." ${ }^{97}$ He stated openly that Islamists in Turkey are not thinking of establishing a state based on Islam. ${ }^{98}$ Instead, Erdoğan was for "making peace with the military, judiciary, and the [secular] capital." 99

\section{Continuity in Substance and Change in Style}

From the moment Erdoğan started to play a leading role in the Innovators' movement in the Virtue Party, the secularist media in Turkey began attacking his claim that he was not interested in establishing a state based on Islam. Erdoğan has been portrayed as an incurable fundamentalist. On August 14, 2001, the Justice and Development Party was founded and Erdoğan was elected its leader. Immediately, the intensity of criticism directed at him increased. It culminated in the Turkish Republic's Chief Prosecutors' demand that the constitutional court should terminate Erdoğan's founding member status of the AKP because of his 1998 conviction, while the prosecutor of a lower court initiated a trial for a speech Erdoğan had made in $1992 .{ }^{100}$ In this speech, he had argued that one could not be both a secularist and a Muslim. This was taken to mean that Erdoğan longed for an Islamic political order.

Both moves against Erdoğan were made on August 21, 2001. On August 24, 2001, Erdoğan held a media conference and a couple of days later agreed to be interviewed by a journalist from the Istanbul daily Hürriyet. In both instances, he addressed the issue of whether or not he had changed. Not unexpectedly, his response to this query was both in the negative and affirmative. He said he had not changed in the sense that he was still proud of subscribing to the values of civilization and history of his countrymen and the moral values that he and his party wish to inject into politics. On the other hand, he said, changing, that is drawing lessons from past experience, is a virtuous act. As an example, he mentioned that he now he supports Turkey's entry into the European Union (EU). ${ }^{101}$ Three days later, on August 27, 2001, he clarified what he had in mind when he made the notorious 1992 speech. He argued that Muslims think that the source of 'right' is God, whereas some secularists claim that that source is man, and 
not God. According to Erdoğan, in the latter view, secularism becomes another religion, and this is not acceptable. He thus went on to argue that just as a person cannot have two religions, one cannot be both secularist and Muslim. ${ }^{102}$

Erdoğan's basic goal has not changed; he still seeks to elevate his fellow human beings, not through the establishment of a state based on Islam, but via personal improvement. However, he now thinks that to achieve the moral development he has in mind, one should no longer resort to a discourse based on themes and concepts derived from Islam. That is, one should not call a struggle ' $j i h \bar{a} d$ ' when one is not trying to spread Islam by force; one should not say one is for $\operatorname{Sharit}^{-} a b$ when one is not interested in de-secularizing the constitutional and legal system in Turkey. He must have come to the conclusion that when he sticks to his own terminology, he is often misunderstood. He does not want to be seen a person who tries to impose his own value system on others.

Before turning to Erdoğan's new style in politics, it is important to reiterate that the changes one observes in Erdoğan are not from his pursuing political Islam to bring about moral development at the individual level only. Erdoğan has never been a subscriber to political Islam. The change that started years ago began first with self-modernization, second, with efforts to bring about a harmonious marriage between Islam and democracy, and third, as noted, avoiding an Islamic discourse.

His self-modernization: Earlier, Erbakan was Erdoğan's idol. He even kissed his hand (in order to show his deep respect). However, he ceased doing so, saying "Hand kissing is a sign of slavery." Erdoğan's clash with Erbakan goes back to the 1978 Congress of the National Salvation Party (MSP). At this congress, Erdoğan joined some others to get certain members of the party elected to the Party's Executive Board, against Erbakan's wish. As early as the late 1970s, Erdoğan was in favor of focusing on the political rather than the spiritual dimension the MSP. ${ }^{103}$ In 1991, Erdoğan did not approve the Virtue Party's (FP) election alliance with the Nationalist Work Party (Milliyetçi Çalişma Partisi-MÇP). At the time, Erdoğan was on the party's Executive Board. Finally, from the mid-1990s onward, Erdoğan became openly critical of Erbakan's hegemony over the party. At the FP's Congress on May 14, 1996, Erdoğan pointed out that in Turkey, leader-dominated politics should be replaced by grass-roots democracy, and that here the FP should take the lead. ${ }^{104}$ In 1998, in a speech in the city of Trabzon on the eastern coast of the Black Sea, Erdoğan stated that one should no longer give direction to politics from one's "ivory tower." 105 Following the ban on Erbakan's active political life, Erdoğan quipped, "Five years from now Erbakan would at most remain a sage." 106 
After becoming the head of the Istanbul provincial branch of the party (1985), Erdoğan made it possible for women to take active part in politics in the ranks of the RP. For the first time, he introduced music to the party's election campaigns. On the eve of the 1994 local elections, he equipped the election headquarters of the party with the latest electronic gadgets, including computers. For election campaigns, he recruited young men without beards, wearing modern suits with ties. ${ }^{107}$

While mayor, he adopted modern management techniques. He made good use of professional staff. ${ }^{108}$ He made it his policy to seek expertise over piety. ${ }^{109}$ He also consulted with university staff members. He placed emphasis on teamwork and participatory decision-making. Under his leadership, the Istanbul Metropolitan Municipality made use of such managerial tools as contracting out services and client-centered marketing.

The successful marriage between Islam and democracy: Anxious to act in a responsive manner to the needs and aspirations of the people, Erdoğan set up a desk in the municipality — the "White Table" (Beyaz Masa) — where people could request new services or seek improvement of existing ones. In addition, every week in different neighborhoods, surveys were conducted to collect residents' opinions on problems they faced and possible solutions to those problems. The municipality's web site carried Erdoğan's email address and those of other key officials of the municipality; this was another channel by which people could convey their woes to the municipality. Another means of access to the municipality was a special telephone line that could be used to report uncollected garbage or similar problems. Municipality functionaries regularly toured the neighborhoods on motorcycles to find out if there was a lapse in service. In each neighborhood, there were "honorary inspectors" (fahri müfettisler) who also monitored the provision of services.

Erdoğan's municipality was quite successful in meeting the myriad needs of Istanbul. The municipality quickly put into use six dams - Elmalidere, Sultanbahçedere, Kazandere, Madradere, Çavuşdere, and Panayirdere. Many of the water pipelines carrying water from existing dams to the city were improved. A drinking water distribution company was set up in order to provide water at less expensive rates. ${ }^{110}$ For decreasing air pollution, industrial plants were obliged to strictly conform to the relevant rules and regulations. New green areas were created. The work on the infrastructure for natural gas and subway was speeded up. ${ }^{111}$ New crossroads and car parks were put into use. Last, but not least, new bus and sea shuttle services were started. ${ }^{112}$

After serving his sentence, Erdoğan said: "We have now left behind conducting politics with religious symbols. On the other hand, we shall show everybody how believers should act in politics." 113 As noted, he was trying to say that they would no longer use a discourse that would seem to the 
secular establishment as an inclination towards Shari ${ }^{-} a h$ rule. Erdoğan was no longer to make such statements as, "Thank God, I am for Shari ${ }^{-} a h$," "For us democracy is a means to an end," "My reference is Islam," and "One cannot be a secularist and a Muslim at the same time." Erdoğan became careful not only with his words but with his deeds. Close to half the group that took the documents for the founding of the Justice and Development Party to the Ministry of Interior were women, and none of them covered their hair. When Erdoğan laid a wreath at Atatürk's Mausoleum in Ankara, again, all the women who accompanied him wore modern dresses. Although it was initially in the program, the chanting of Fätihah was skipped at the first meeting. ${ }^{114}$

At the same time, Erdoğan clung to his original goal of elevating morality among the people. When he played a primary role in the jelling of a serious schism in the Virtue Party, he argued that there was only one target for politics and it was the effort to upgrade morality. ${ }^{115}$ Thus, he and others in the party started the "Movement of the Virtuous" (Erdemliler Hareketi) that culminated in the formation of the Justice and Development Party. Erdoğan was elected chairperson.

Erdoğan pointed out that, as the name of his party implied, the party's goal was to solve Turkey's pressing problems. He explained that the Turkish justice system was suffering from the fact that people basically distrusted the judiciary and longed for true justice. Erdoğan also noted that for several years, people in Turkey had been badly hit by inflation and unemployment and that there was an urgent need for overhauling the economy. ${ }^{116}$

Not unexpectedly, Erdoğan's Justice and Development Party also:

(1) underlined the significance of morality, trust, and merit in politics;

(2) perceived religion as one of the most important institutions of humanity;

(3) pledged loyalty to the principles of the Republic and the Constitution;

(4) defined secularism as an orienting principle for the state but not for the individual, and thus referred to secularism as a means to freedom and social harmony and took it as a guarantee of freedom of conscience; (5) rejected the use of religion as well as ethnicity for political benefit; (6) promised to strike a healthy balance between indigenous values and global norms; (7) stressed the significance of mutual respect, harmony and cooperation in political life; (8) condemned personal rule and political patronage and praised collective reasoning leading to well-thought out policies and their effective and efficient execution; and (9) took as its basic reference the United Nations Charter of Human Rights and the European Charter for the Protection of Human Rights and Basic Liberties. ${ }^{117}$

When Erdoğan was elected the chairperson of the party, he stated that "... nothing will be like the old." In the background played The Conquest 
of Paradise, the theme music of the movie 1492, which is about the discovery of America. In his acceptance speech, Erdoğan quoted Voltaire, one of the leading philosophers of the French Enlightenment: "I do not agree with you, but I would do everything I can so that you would be able to express your views freely." The symbol of the party was a lighted electric bulb; while Erdoğan talked, there were on the wall behind him a Turkish flag, a picture of Atatürk, and a poster that read, "We Are Open to Light and Closed to Darkness." ${ }^{118}$ In none of this one could observe an explicit reference to Islam.

\section{Discussion}

Erdoğan may change the interface of Islam and politics in Turkey. People in Turkey do not want to establish an Islamic state. Though sincere believers, they took in their day-to-day behavior cues from non-Islamic premises. Neither is he interested in political Islam. However, having come to the conclusion that the non-Islamic premises in question have not morally uplifted people in Turkey, he wishes to replace them with Islamic ones.

It is true that Erbakan and his close colleagues were interested in improving people's morality. Yet, they were not consistent. From time-to-time not only the militant members of all religiously oriented political parties - from the National Order party to the Virtue party — but also Erbakan himself made statements that could justifiably be construed as pro-political Islam. Erdoğan gives the impression that he will not pursue a similar tactic of appeasement towards those rank-and-file in his party that may have radical Islamist views.

When he was mayor, Erdoğan had hardly been engaged in acts that could be construed as a threat to Turkey's efforts to consolidate its democracy. His statements, which were taken by the majority of secularists in that country as signs of longing for political Islam, in fact, targeted unhindered moral development. It should be kept in mind that in the Qurān, there are two meanings of government. According to one, all aspects of life in society must conform strictly and exclusively to Islamic prescriptions; according to another, the ordering of society in its political aspects should conform to the general norms and principles of Islam. ${ }^{119}$ Erdoğan's project comes close to the second meaning of government.

It is true that in his attempts to upgrade morals in the community, Erdoğan has not only advised people to seek goodness that emanates from God, but, whenever he had the authority, he also tried to 'save' people from the temptation to ignore the 'right' God radiates. However, he thought it was up to the people themselves whether or not to heed his counsel. Lately, by stating that in the future his politics will not have a religious discourse, he seems to have come to the conclusion that even such 'innocent' remarks are not appropriate in a country making every effort to institutionalize a secular-democratic state. 
The present Erdoğan project aims at political Islam, but does not clash with a liberal-democratic state. Would it thus make sense to suggest that not only has Turkey been the first Muslim country that has longed for democracy, but that the evolution of the Islam-democracy relationship in that country as seen in the Erdoğan project can contribute to the consolidation of democracy there? In an earlier study, one of the present authors had suggested the following: "A marriage between Islam and democracy in Turkey can be consummated if the radical secularists stop trying to impose their preferred life-style and set of values upon the Islamists, and if the latter do not undermine by word or deed the basic tenets of the secular democratic state in Turkey." ${ }^{\prime 20}$ Presently, Erdoğan-type Islamists are resolved not to challenge through word or deed the basic premises of the secular democratic state Turkey wants to institutionalize. However, the majority of secularist elite in that country are not ready to accommodate Erdoğan-type Islamists in their ranks. The latter continue to see any kind of Islam as retrogressive. Even Erbakan's words, let alone the more radical Islamists and the recent deeds of the marginal and isolated Hizbullah in Turkey, have only reinforced their conviction that Islam itself is incurable and Islamists are narrow-minded and bigoted. Recent statements on Erdoğan's part, such as "Turkey should have as large a population as it could have" have confirmed suspicions about his project.

This particular attitude on the part of secularists in Turkey constitutes a serious obstacle for the consolidation of democracy there. As Alfred Stepan noted, in the early twentieth century, it was in 1905 France and 1931 Spain that one came across the two most hostile separations of church and state.

However, both France and Spain later came to have a friendlier separation of those two institutions. Today, virtually no Western European democracy has a hostile separation between them. The so-called "twin tolerations" have become the distinguishing characteristic of Western European democracy. ${ }^{121}$

Our view is that the Erdoğan project is not pro-political Islam, and we believe it is not optimistic to suggest that sooner or later this fact will be recognized. Some influential columnists like Ertuğrul Özkök of Hürriyet and Hasan Cemal of Milliyet as well as Prime Minister Bülent Ecevit are ready to give him the benefit of the doubt. The military, another of his detractors, has on occasion not been averse to changing its mind, if presented with persuasive evidence.

Still, there is a critical issue standing in the way of the further consolidation of democracy in Turkey. Perceived political integrity on the part of political actors is indispensable for a viable democracy to flourish. Distrust of politicians would put into peril the very legitimacy of a political system. For some time now, Turkish democracy has been suffering from a political legitimacy crisis arising out of serious misgivings on the part of the people towards politicians. 
A recent study has shown that in that country "democracy is equated with populism practiced through clientelistic networks, which often requires the bending of rules and laws to distribute benefits to ... organised interests and blocs of voters." 122

This seems to be the reason why, according to recent opinion polls, Erdoğan has become very popular among the people. The Erdoğan project tries to grapple with the legitimacy crisis by injecting values derived from Islam into politics. At the other end of the political spectrum, Devlet Bahçeli, Deputy Prime Minister and the leader of the Nationalist Action Party (Milliyetçi Hareket Partisi-MHP), is trying to do the same by invoking patriotism derived from cultural nationalism. The problem is that while both the Justice and Development Party and the MHP aim at being centrist parties, given their continuing rejection by the majority of those with secularist worldviews, these two parallel efforts may still lead Turkey into a deep cultural cleavage. Such an eventuality does not bode well for the consolidation of democracy.

\section{Endnotes}

1. On 'Muslim secularism' and its adoption in Egypt and several other Muslim countries, see William E. Shepard, "Muhammad Sa'id Al-'Ashmawi and the Application of the Sharīa in Egypt," International Journal of Middle East Studies, 28 (1996), 41.

2. See, inter alia, Howard Reed, "Revival of Islam in Secular Turkey," Middle East Journal, vol. 8 (1954): 267-82.

3. Bernard Lewis, "Why Turkey is the Only Muslim Country?" Middle East Quarterly, vol. 1, no. 1 (1994): 41-9. For an elaboration on the historical dynamics that made it possible, see Metin Heper, "The State, Religion, and Pluralism: The Turkish Case in Comparative Perspective," British Journal of Middle Eastern Studies, vol. 8, no. 1 (1991): 38-51.

4. Abdou Filali-Ansary, "Muslims and Democracy," Journal of Democracy, vol. 10, no. 3 (July 1999), 20-21.

5. On 'the moral community' of the Ottoman times, see Şerif Mardin, "The Just and Unjust," Daedalus, vol. 120, no. 3 (Summer 1991), 115.

6. Muhammed Pamuk, Yasakh Umut: Recep Tayyip Erdoğan (Istanbul: Birey, 2001), $144-45$.

7. Milliyet (Istanbul daily), June 27, 2001.

8. Ibid., August 4, 2001.

9. The interview with Recep Tayyip Erdoğan by one of the authors (Şule Toktaş) on November 21, 2001. Below, "The Interview."

10. More about this below.

11. Turan Yılmaz, Tayyip: Kasimpaşa'dan Siyasetin Ön Saflarma (Ankara: Ümit, 2001), 229. Here and below, the translations from Turkish to English have been rendered by the present authors.

12. Ibid., 178.

13. Recep Tayyip Erdoğan, Bu Şarkı Burada Bitmez, seventh printing, compiled by İbrahim Ethem Deveci (Istanbul: Nesil, 1999), 29. 
14. Ruşen Çakır and Fehmi Çalmuk, Recep Tayip Erdoğan: Bir Dönüşüm Öyküsü (Istanbul: SiyahBeyaz, 2001), 16-18.

15. Kıvanç Koçak, 'Kasımpaşalı Haylaz: Merkez Sağda Yeni Umut', Birikim (Istanbul), no. 147 (July 2001), 56.

16. Ibid., 21.

17. Ibid., 46.

18. Y1lmaz, Tayyip, 256.

19. Ibid., 250. We think Erdoğan has been against the de-Islamization of the society to an unnecessary extent rather than the Islamization of the state.

20. Ibid., 61.

21. Ibid., 81.

22. Zaman (Istanbul daily), October 4, 1998.

23. The interview. Our emphasis.

24. The interview.

25. www.haberturk.com (June 16, 2001)

26. Yilmaz, Tayyip, 36-7.

27. Pamuk, Yasakl Umut, 21-22.

28. Şerif Mardin, "The Nakşibendi Order in Turkish History," in Islam in Modern Turkey: Religion, Politics and Literature in a Secular State, Richard Tapper, ed. (London: I.B. Tauris, 1991).

29. Çakır and Çalmuk, Recep Tayyip Erdoğan, 30.

30. The interview.

31. On Sufism, here and below, we draw upon Mark J. Sedgwick, Sufism: The Essentials (Cairo: The American University in Cairo Press, 2000).

32. Çakır and Çalmuk, Recep Tayyip Erdoğan, 21.

33. We return to this episode below.

34. Zaman, September 25, 1998.

35. Cited in Y1lmaz, Tayyip, 18-19.

36. Ibid., 33 .

37. Ibid., 108. The Ottoman Islamic Imam administered the Shari ${ }^{-} a b$ under the guidance of divine wisdom. See Mardin, "The Just and Unjust," 118. In the Medinese Verses of the Qur'ān, the Prophet is presented not only the as bearer of God's message, but also as possessor of superlative authority to which all Muslims should submit. See Faruq Sherif, A Guide to the Contents of the Qur'an (Reading, UK: Garnet, 1995), 7.

38. Yilmaz, Tayyip, 85.

39. Ibid., 116.

40. Erdoğan, Bu Şarkı Burada Bitmez, 65.

41. Sufis always search for the deeper meanings hidden beneath the literal, surface sense of the Qur'ān. See P. J. Stewart, Unfolding Islam (Reading, UK: Garnet, 1994), 176.

42. Pamuk, Yasakl Umut, 95.

43. Erdoğan, Bu Şarkı Burada Bitmez, 63.

44. Yilmaz, Tayyip, 91.

45. Erdoğan, Bu Şarkı Burada Bitmez, 57.

46. Yilmaz, Tayyip, 108.

47. Ibid., 90.

48. William E. Shepard, "Islam and Ideology: Towards a Typology," International Journal of Middle East Studies, 19 (1987), 310.

49. Erdoğan, Bu Şarkı Burada Bitmez, 59.

50. Ibid., 43-44. 
51. See Erdoğan, Bu Şarkı Burada Bitmez, 16-17.

52. Y1lmaz, Tayyip, 119.

53. Ibid., 81.

54. Çakır and Çalmuk, Recep Tayyip Erdoğan, 178-9.

55. Oktay Ekinci, Şeriatın Kravath Başkanı (Istanbul: Çăgdaş, 1998), 15, 19.

56. We return to this speech and his conviction thereof below.

57. www.rerdoğan.com/ruzname/98/22usu98.htm. Our emphasis.

58. Pamuk, Yasakl Umut, 92.

59. Ibid., 25.

60. Erdoğan, Bu Şarkı Burada Bitmez, 65.

61. Yilmaz, Tayyip, 117.

62. Pamuk, Yasakl Umut, 94.

63. See Mardin, "The Just and the Unjust," 115. Mardin has shown that in the early centuries of the Ottoman Empire, the 'just' in this sense was a datum of both the center and the periphery. When the center began to go through a Westernizing process, 'just' became associated only with the periphery. It continued to figure as such in the Republican period too. On justice being the most important norm of the early Ottoman official philosophy, see Halil İnalc1k, "The Nature of Traditional Society [Turkey]" in Political Modernization in Japan and Turkey, Robert E. Ward and Dankwart A. Rustow, eds. (Princeton: Princeton University Press, 1964).

64. Nokta (Istanbul weekly), September 18-24, 1994.

65. Erdoğan, Bu Şarkı Burada Bitmez, 63.

66. Nokta, September 18-24, 1994.

67. Y1lmaz, Tayyip, 191.

68. Zaman, December 19, 1998.

69. Pamuk, Yasakl Umut, 127.

70. Nokta, September 18-24, 1994.

71. Pamuk, Yasakl Umut, 174-75.

72. Yilmaz, Tayyip, 260, 263.

73. Recep Tayyip Erdoğan Davası, compiled by Faik Işık (Istanbul: Birleşik Avukatlar, 1998), passim.

74. In any case, law is not the forte of either of the present authors.

75. Unless otherwise stated, the following account of the Siirt speech and its aftermath draws upon Recep Tayyip Erdoğan Davasi.

76. Erdoğan, Bu Şarkı Burada Bitmez, 56.

77. Y1lmaz, Tayyip, 111.

78. Hürriyet, March 27, 2000.

79. Hürriyet, August 28, 2001. Our emphasis.

80. Çakır and Çalmuk, Recep Tayyip Erdoğan, 113.

81. Recep Tayyip Erdoğan Davasi, v.

82. Ibid., 160-61.

83. Hürriyet, June 29, 2001.

84. Erdoğan, Bu Şarkı Burada Bitmez, 65.

85. Çakır and Çalmuk, Recep Tayyip Erdoğan, 179.

86. It must also be noted here that Erdoğan had first read his Siirt poem in question at the Prayer Leader and Preacher School that he had attended. See Çakır and Çalmuk, Recep Tayyip Erdoğan, 21.

87. Recep Tayyip Erdoğan Davası, v.

88. Çakır and Çalmuk, Recep Tayyip Erdoğan, 122.

89. Pamuk, Yasaklı Umut, 32. 
90. Türk ve Türklük, compiled by Ömer Naci Bozkurt (Ankara: Türk Standartlar1 Entitüsü, [1994]). In his defence, Erdoğan has pointed out that many of the ideas in his speech were derived from this book. Indeed, the book in question has emphasised the need for harmony, argued that the state and religion are not the enemies of each other, suggested that love for God promoted one to an exalted rank by causing in one the will to become virtuous, and pointed out that religion was, among other things, a source for morality $(274,283,284-85)$. This book must have had a significant impact on Erdoğan; his speech revolved around the themes in question despite the fact that he had made that speech impromptu.

91. Recep Tayyip Erdoğan Davası, 27.

92. Pamuk, Yasakl Umut, 95.

93. The poem is by renowned poet Necip Fazıl Kısakürek, for whom Erdoğan has great respect. Kısakürek too had a Sufi understanding of Islam, and thought that the Right should always inform our day-to-day behaviour. See Burhanettin Duran, "Transformation of Islamist Political Thought in Turkey from the Empire to the Early Republic (1908-1960): Necip Fazıl Kisakürek's Political Ideas,” unpublished Ph.D. dissertation, Department of Political Science and Public Administration, Bilkent University, Ankara, 2001.

94. Recep Tayyip Erdoğan Davası, v, 274-75.

95. Tempo (Istanbul weekly), 18 January 1995.

96. Ekinci, Seriatın Kravath Başkanı, 198.

97. Erdoğan, Bu Şarkı Burada Bitmez, 56.

98. Hürriyet, August 27, 2001.

99. Çakır and Çalmuk, Recep Tayyip Erdoğan, 101.

100. The Republic's chief prosecutor's move was found controversial, because another politician, Hasan Celal Güzel, who had been sentenced according to the same Article in the Penal Code that Erdoğan was sentenced, was later allowed to become a member of a political party by the Constitutional Court. This was because recent legislation had made possible conditional release for those convicted in accordance with the Article in question. The action taken by the prosecutor was also considered questionable because earlier legal proceedings had been started against Erdoğan for the 1992 speech but were stopped because of legal limitation. The prosecutor accused Erdoğan in accordance with another Article (Article 312).

101. Hürriyet, August 24, 2001.

102. Hürriyet, August 27, 2001.

103. Çakır and Çalmuk, Recep Tayyip Erdoğan, 98.

104. Yilmaz, Tayyip, 198.

105. Ibid., 199.

106. Ibid.

107. Pamuk, Yasakl Umut, pp. 16, 27, 30, 138 and Y1lmaz, Tayyip, 59.

108. Unless otherwise noted, on Erdoğan's mode of operation as mayor we draw upon Mehmet Emin Gerger, Belediyelerden İktidara Refah (Istanbul: Çevre, 1996).

109. Çakır and Çalmuk, Recep Tayyip Erdoğan, 64-66.

110. Erdoğan, Bu Şarkı Burada Bitmez, 84-5.

111. Ibid., 30 .

112. Ibid., 134.

113. Yilmaz, Tayyip, 23.

114. Hürriyet, August 18, 2001; Sabah, August 17, 2001; Milliyet, August 24, 2001.

115. www.re/dogan.com/bulten/hzr 95-19-3.htm.

116. Yeni Şafak, August 16, 2001. 
117. Sabah, August 15, 2001; Hürriyet, August 15, 2001; Yeni Şafak (Istanbul daily), August 15, 16, 17, 2001; and Çakır and Çalmuk, Recep Tayyip Erdoğan, 244.

118. Hürriyet, August 24, 2001; Yeni Şafak, August 24, 2001; Milliyet, August 24, 2001.

119. Sherif, A Guide to the Contents of the Qur'ann, 202-3.

120. Metin Heper, "Islam and Democracy in Turkey: Toward a Reconciliation?" Middle East Journal, vol. 51, no. 1 (Winter 1997), 45.

121. Alfred Stepan, "Religion, Democracy, and the "Twin Tolerations," Journal of Democracy, vol. 11, no. 4 (October 2000), 42.

122. Ersin Kalaycioğlu, "Turkish Democracy: Patronage versus Governance," Turkish Studies (London), vol. 2, no. 1 (Spring 2001), 67. 


\section{Postscript}

On November 3, 2002, national elections were held in Turkey. Although Erdoğan still led the AKP he could not run in the elections as there was still a legal ban on his being elected to Parliament. Despite this handicap, the AKP obtained the 34.5 percent of the votes in an 18-party election, and came to have an absolute majority in Parliament. The orthodox Felicity Party as well as the three government parties - the Democratic Left Party, Nationalistic Action Party, and the Motherland Party — and the main opposition party — the True Path Party - could not clear the ten-percent election barrier and were thus left out of Parliament. The AKP formed the government; the left-of-center Republican People's Party became the sole opposition party.

In the post November 3, 2002, period, Erdoğan continued to function as the leader of the AKP, while Abdullah Gül became the caretaker prime minister. In January, 2003, Erdoğan's ban was lifted. It is expected that in March or April, 2003, Erdoğan will enter Parliament through by-elections that will be held in one or two constituencies, and take over the prime ministry from Gül.

In the evening of November 3, 2003, as it gradually became clear that the AKP was coming to power all by itself, the secular inteligentsia became alarmed. In the public statements that he made on the election night and during the subsequent weeks, Erdoğan began to assuage those fears. He pointed out that (1) the AKP will be respectful to everybody's life styles; (2) the party will do everything it can to accelarate the AKP government; (3) Turkey will continue to welcome foreign capital: (4) the AKP's approach to the question of secularism will be no different from what has been stipulated on that matter in the Constitution; and (5) the problem of veiled students at universities will not be the government's priority.

Immediately following the elections, Erdoğan made several trips to several EU capitals as well as Washington, D. C. Among others, he had talks with President George Bush and British, Dutch, French, German, Greek, Italian, and Spanish prime ministers. During the crucial Copenhagen meeting of the EU prime ministers in December, 2002, Erdoğan was joined by Gül; together they made great efforts to obtain a negotiating date for Turkey's full accession to the EU. When the EU failed to give a definitive date, Erdoğan and Gül became quite disappointed, but they took it in good spirit. Erdoğan even quipped: "From this moment on we shall strive to make the Copenhagen criteria [concerning political liberalisation] Ankara criteria."

Turning to domestic politics, Erdoğan interpreted the October, 2003, elections by arguing that since the party had obtained votes from all the cross-sections of the electorate, it was clear that the AKP was not a religiously 
oriented party, but that it was a center-right party. He later pointed out that because the AKP had an absolute majority in Parliament, they were able to form a strong government; however, he added, "the AKP government will also be a responsible government." By the latter statement, he was pointing out that the government was not going to carelessly trample over secularist sensitivities in the country. Indeed, whenever some isolated members of the AKP government or Parliamentary Group seemed to bring to the political agenda such sensitive issues, Erdoğan warned them by saying, "We matters." 